\title{
Are Alpha-Fetoprotein Based-Vaccines Potential Tools for Liver Cancer Therapy?
}

Roberto Bei*

Department of Clinical Sciences and Translational Medicine, University of Rome "Tor Vergata", Rome, Italy

Alpha-Fetoprotein (AFP) is a tumor-associated oncofetal antigen consisting of a single polypeptide chain with a molecular mass of 69 $\mathrm{kDa}$ and a carbohydrate content of 3-5\% [1]. AFP is produced in the fetal yolk sac at 9 weeks of gestation, and later in the fetal liver and gastrointestinal tract [1]. AFP binds and transports a multitude of ligands and is re-expressed in adult life in several tumors including hepatomas, hepatoblastomas, pancreatic, stomach, yolk sac tumors, and teratomas [2]. Accordingly, serum AFP has been employed as a biomarker to monitor cancer recurrence after treatment and to reveal pregnancy and neonatal disorders [2]. However, the specificity and sensitivity of serum AFP values change according to the cut-off value employed in Hepatocellular Carcinomas (HCC) [2].

Recently, it has been demonstrated that AFP can exert immunomodulatory and immunosuppressive activities in vitro. Indeed, Natural Killers (NKs), activated lymphocytes, Cytotoxic T Lymphocytes (CTLs) and Antigen Presenting Cells (APCs) can be immunosuppressed by AFP [3-5]. On the other hand, humoral and T cell immune responses to AFP have been detected in patients affected by HCC or other liver diseases including cirrhosis [6,7]. High titers of anti-AFP antibodies in HCC (14/60), liver cirrhosis (3/15) and chronic hepatitis $(1 / 15)$ patients but not in 40 healthy individuals were detected [6]. Butterfield et al. demonstrated for the first time that human T-cells can recognize AFP epitopes in the context of HLA-A2.1 [7]. In addition, AFP peptide-specific $T$ cells were able to recognize AFP-transfected cells [8]. Based on these studies, different AFP peptides were identified as "immunodominant" according to their strong binding to MHC I, in vitro high-level production of IFN- $\gamma$ and activation of CTLs from stimulated healthy donor T cells $[7,8]$. These evidences have supported the design of AFP-based cancer vaccines, although AFP is a self antigen. Indeed, different studies have reported that tolerance to AFP could be interrupted [6-8]. Different approaches of immunization, including the delivery of AFP (alone or with cytokines) by DNA, Dendritic Cells (DCs), viral vectors or as a recombinant protein as well as different experimental models have been used to evaluate whether AFP immunization could induce a protective immunity in HCC bearing animals [9-12]. Vaccination with DCs carrying AFP epitopes or AFP-plasmid DNA has been demonstrated to inhibit the growth of transplanted syngeneic AFP-positive hepatoma cell lines without inducing autoimmune reactions against the regenerating liver $[11,12]$. Overall, AFP-based cancer vaccines have shown encouraging results in preclinical studies. In agreement with these preclinical results, clinical trials were carried out in patients with HCC $[13,14]$. Butterfield et al. performed two trials in heavily pre-treated HCC patients using AFPderived peptides delivered in adjuvant or carried by DCs. The authors demonstrated that patients generated T-cell responses to most or all of the peptides without evidence of toxicity. However, these trials did not achieve significant objective clinical responses $[13,14]$. Other human studies were conducted to find modalities to implement immune responses to AFP for future clinical trials.

Major concerns for the use of AFP as an anti-cancer vaccine rely on the fact that AFP is a self antigen, exerts an immunosuppressive activity, inhibits apoptosis of cancer cells and stimulates the expression of some oncogenes [1,3-5,9]. On the other hand, no adverse reactions due to autoimmune phenomena have been observed in preclinical and clinical trials and AFP immunization was shown to induce a strong immune response both in immunized animals and humans [9,1114]. In addition, both native AFP and a recombinant AFP fragment of about 300 amino acids composed of the last half of the full-length AFP molecule were demonstrated to inhibit the growth of estrogendependent breast cancer cells transplanted in mice $[15,16]$.

Overall, although preclinical studies employing AFP-based vaccines were satisfactory, results in HCC patients were not encouraging. Accordingly, further studies are necessary to better elucidate the effects of AFP-based cancer vaccines on the innate and adaptive immunity, to develop new vaccine scheduling and to improve the use of the vaccine in clinical trials. It will be necessary to envisage new clinical trials combining AFP-based cancer vaccines with conventional therapies to better prevent and treat AFP-expressing tumors in patients.

\section{References}

1. Mizejewski GJ (1995) The phylogeny of alpha-fetoprotein in vertebrates: survey of biochemical and physiological data. Crit Rev Eukaryot Gene Expr 5: 281-316.

2. Mizejewski GJ (2002) Biological role of alpha-fetoprotein in cancer: prospects for anticancer therapy. Expert Rev Anticancer Ther 2: 709-735.

3. Cohen BL, Orn A, Gronvik KO, Gidlund M, Wigzell H, et al. (1986) Suppression by alpha-fetoprotein of murine natural killer cell activity stimulated in vitro and in vivo by interferon and interleukin 2. Scand J Immunol 23: 211-223.

4. Ritter M, Ali MY, Grimm CF, Weth R, Mohr L, et al. (2004) Immunoregulation of dendritic and $T$ cells by alpha-fetoprotein in patients with hepatocellular carcinoma. J Hepatol 41: 999-1007.

5. Semeniuk DJ, Boismenu R, Tam J, Weissenhofer W, Murgita RA (1995) Evidence that immunosuppression is an intrinsic property of the alphafetoprotein molecule. Adv Exp Med Biol 383: 255-269.

6. Bei R, Budillon A, Reale MG, Capuano G, Pomponi D, et al. (1999) Cryptic epitopes on alpha-fetoprotein induce spontaneous immune responses in hepatocellular carcinoma, liver cirrhosis, and chronic hepatitis patients. Cancer Res 59: 5471-5474.

7. Butterfield LH, Koh A, Meng W, Vollmer CM, Ribas A, et al (1999) Generation of human T-cell responses to an HLA-A2.1-restricted peptide epitope derived from alpha-fetoprotein. Cancer Res 59: 3134-3142.

8. Butterfield LH, Meng WS, Koh A, Vollmer CM, Ribas A, et al. (2001) T cell responses to $\mathrm{HLA}-\mathrm{A}^{*} 0201$-restricted peptides derived from human alpha fetoprotein. J Immunol 166: 5300-5308.

*Corresponding author: Roberto Bei, Department of Clinical Sciences and Translational Medicine, University of Rome "Tor Vergata", Faculty of Medicine, Via Montpellier 1, 00133, Rome, Italy, Fax: + 39 06-72596506; E-mail: bei@med.uniroma2.it

Received November 29, 2012; Accepted November 30, 2012; Published January 06, 2013

Citation: Bei R (2013) Are Alpha-Fetoprotein Based-Vaccines Potential Tools for Liver Cancer Therapy? J Liver 2:e103. doi:10.4172/2167-0889.1000e103

Copyright: (c) 2013 Bei R. This is an open-access article distributed under the terms of the Creative Commons Attribution License, which permits unrestricted use, distribution, and reproduction in any medium, provided the original author and source are credited. 
Citation: Bei R (2013) Are Alpha-Fetoprotein Based-Vaccines Potential Tools for Liver Cancer Therapy? J Liver 2:e103. doi:10.4172/2167$0889.1000 \mathrm{e} 103$

9. Bei R, Mizejewski GJ (2011) Alpha fetoprotein is more than a hepatocellular cancer biomarker: from spontaneous immune response in cancer patients to the development of an AFP-based cancer vaccine. Curr Mol Med 11: 564-581.

10. Bei R, Scardino A (2010) TAA polyepitope DNA-based vaccines: a potential tool for cancer therapy. J Biomed Biotechnol 2010: 102758.

11. Tan XH, Zhu Q, Liu C, Liu XL, Shao XT, et al. (2006) Immunization with dendritic cells infected with human AFP adenovirus vector effectively elicits immunity against mouse hepatocellular carcinomas. Zhonghua Zhong Liu Za Zhi 28: 13-16.

12. Grimm CF, Ortmann D, Mohr L, Michalak S, Krohne TU, et al. (2000) Mouse alpha-fetoprotein-specific DNA-based immunotherapy of hepatocellular carcinoma leads to tumor regression in mice. Gastroenterology 119: 1104 1112.

13. Butterfield LH, Ribas A, Meng WS, Dissette VB, Amarnani S, et al. (2003)
T-cell responses to HLA-A*0201 immunodominant peptides derived from alpha-fetoprotein in patients with hepatocellular cancer. Clin Cancer Res 9 . 5902-5908.

14. Butterfield LH, Ribas A, Dissette VB, Lee Y, Yang JQ, et al. (2006) A phase I/ II trial testing immunization of hepatocellular carcinoma patients with dendritic cells pulsed with four alpha-fetoprotein peptides. Clin Cancer Res 12: 28172825.

15. Bennett JA, Semeniuk DJ, Jacobson HI, Murgita RA (1997) Similarity between natural and recombinant human alpha-fetoprotein as inhibitors of estrogendependent breast cancer growth. Breast Cancer Res Treat 45: 169-179.

16. Bennett JA, Zhu S, Pagano-Mirarchi A, Kellom TA, Jacobson HI (1998) Alphafetoprotein derived from a human hepatoma prevents growth of estrogendependent human breast cancer xenografts. Clin Cancer Res 4: 2877-2884. 